\title{
Transferrin Synthesis by Inducer T Lymphocytes
}

\author{
J. B. Lum, A. J. Infante, D. M. Makker, F. Yang, and B. H. Bowman \\ Department of Cellular and Structural Biology, Departments of Pediatrics and Microbiology, The University of Texas Health Science \\ Center at San Antonio, San Antonio, Texas 78284
}

\begin{abstract}
Transferrin (Tf) is a growth factor that transports iron in plasma. It is essential for proliferation of activated T lymphocytes. Previous studies have suggested that peripheral blood cells are capable of synthesizing Tf. Using in situ hybridization techniques and human Tf complementary DNAs as probes, peripheral blood cells have been examined for sites of Tf messenger RNA (mRNA) transcription. The studies described here demonstrate that $T f$ is synthesized by a specific subset of $\mathrm{T}$ lymphocytes, the $\mathrm{T4}^{+}$inducer subset. $T$ lymphocyte proliferation is dependent upon the presence of both interleukin 2 (IL-2) and Tf, even though resting cells do not possess receptors for either. The present studies indicate that during $T$ cell activation, induction of IL-2 mRNA transcription and IL-2 receptor expression precede the transcription of Tf $\mathrm{mRNA}$ and expression of Tf receptors, respectively. These events in turn precede the initiation of DNA synthesis. Transferrin and its receptor appear to be involved in an autocrine pathway which is functionally linked to the IL-2/IL2 receptor autocrine loop.
\end{abstract}

\section{Introduction}

Transferrin (Tf), ${ }^{1}$ the major iron-transporting protein in plasma (1), is a glycoprotein with a molecular weight of 79,500 daltons (2). It transports ferric iron from the intestine, reticuloendothelial system, and liver parenchymal cells to all proliferating cells in the body (3). The liver is the major site of Tf synthesis $(1,3)$. Tf is a growth factor required for proliferating normal and malignant cells (4-8); it is an essential component of defined medium used for growth of lymphocytes in vitro. Tf enters cells by receptor-mediated endocytosis (9). After iron is released into an intracellular acidic compartment, apotransferrin is returned to the extracellular environment and recycled many times $(8,9)$. Therefore, it has been difficult to differentiate endogenous from exogenous $\mathrm{Tf}$ within cells by conventional immunologic techniques.

Drs. Infante and Makker are with the Departments of Pediatrics and Microbiology, University of Texas Health Science Center at San Antonio. Address reprint requests to Dr. Bowman.

Received for publication 31 July 1985

1. Abbreviations used in this paper: CLB, cell lysis buffer; $\mathrm{E}^{+}, \mathrm{T}$ enriched sheep erythrocyte; $E^{-}$, T-depleted sheep erythrocyte; EBV-BCL, Epstein-Barr virus-transformed B cell line; FCS, fetal calf serum; FGAMIg, fluoresceinated goat anti-mouse immunoglobulin; IL-1, IL-2, interleukins 1 and 2; MAb, monoclonal antibody; PAGE, polyacrylamide gel electrophoresis; PBMC, peripheral blood monoclonal cell; PHA, phytohemagglutinin; SSC, standard saline citrate; TdR, thymidine; Tf, transferrin.

J. Clin. Invest.

(c) The American Society for Clinical Investigation, Inc. 0021-9738/86/03/0841/09 $\$ 1.00$

Volume 77, March 1986, 841-849
Our laboratory has recently cloned, characterized, and chromosomally mapped the coding sequence of the human $\mathrm{Tf}$ gene (10). Utilization of Tf complementary DNA (cDNA) and a modification of in situ hybridization $(11,12)$ has provided the opportunity for identifying transcription of transferrin. This technique has facilitated detection of Tf messenger RNA (mRNA) in heterogeneous populations of cells where cellular extracts may not contain sufficient levels of Tf mRNA for detection by conventional cDNA-mRNA hybridization on filter blots.

The expansion of clones of lymphocytes is an essential feature of the immune response. $T$ lymphocyte proliferation is controlled by a series of premitotic signals generated by interactions of growth factors and their membrane receptors. When $\mathrm{T}$ cells are activated by mitogenic lectins, antigens, or antibodies against the antigen receptor complex, the series of events known to lead to DNA synthesis and cell proliferation include the expression of the receptor for interleukin 2 (IL-2) (T cell growth factor) (13, 14), IL-2 production $(15,16)$, and Tf receptor expression (1719). In T lymphocyte activation, IL-2 production and IL-2 receptor expression are induced prior to Tf receptor induction. The expression of $\mathrm{Tf}$ receptors is, in the presence of $\mathrm{Tf}$, required for DNA synthesis and cell division. Therefore, the role of IL2 in the stimulation of $\mathrm{T}$ lymphocyte proliferation appears to be due, in part, to induction of Tf receptors $(18,20)$.

IL-2 is produced primarily by a subset of T lymphocytes bearing the cell surface molecule recognized by the monoclonal antibody OKT4 $\left(\mathrm{T}^{+}\right)(21,22)$. The $\mathrm{T}^{+}$subset has been labeled the "inducer" subset, because a major role of these cells is to activate other lymphocytes (i.e., cytotoxic $T$ cells, suppressor $T$ cells, and B cells). This inductive process is mediated by direct cellular communication and by the secretion of a number of other lymphokines. Independent studies suggested that human peripheral blood mononuclear cells (PBMCs) synthesized Tf (23), and that $\mathrm{Tf}$ was localized in the $\mathrm{T}$ cell compartment (24). In the studies reported here, the role of $\mathrm{Tf} \mathrm{mRNA}$ expression in cellular proliferation of mitogen-stimulated and antigen-activated $T$ lymphocytes was examined. Specifically, the relationship of Tf synthesis and $\mathrm{Tf}$ receptor expression to the autocrine pathway involving IL-2 and its receptor in T cell proliferation was investigated.

\section{Methods}

Cell preparation. Human PBMCs were obtained by Ficoll-Hypaque (Sigma Chemical Co., St. Louis, MO) separation of heparinized venous blood drawn from healthy volunteers (25). Blood was diluted twofold with Hanks' balanced salt solution (HBSS), underlaid with Ficoll-Hypaque, and centrifuged at room temperature for $\mathbf{3 0} \mathrm{min}$. Interface cells were removed, washed three times in HBSS, and counted. T cell-enriched and/or T cell-depleted fractions were isolated as follows (26). PBMCs $\left(1-2 \times 10^{7} / \mathrm{ml}\right)$ were added to an equal volume of $5 \%$ sheep red blood cells $\left(\mathrm{E}^{+}\right) .20 \% \mathrm{E}$-absorbed fetal calf serum (FCS) was added (vol/vol). Cells were pelleted and allowed to stand $1-2 \mathrm{~h}$ at $4^{\circ} \mathrm{C}$, then gently re- 
suspended and centrifuged over Ficoll-Hypaque. Interface cells were $\mathbf{E}^{-}$ (non-rosette-forming, T-depleted). Pelleted cells were $\mathrm{E}^{+}$(T-enriched). Contaminating red blood cells were lysed in buffered $\mathrm{NH}_{4} \mathrm{Cl}$ solution. The recovered $\mathrm{E}^{-}$cells were essentially $100 \% \mathrm{E}^{-} ; \mathrm{E}^{+}$cells were 90-95\% $\mathrm{E}^{+}$

For macrophage/monocyte depletion, PBMCs were resuspended at a concentration of $5 \times 10^{6} / \mathrm{ml}$ in RPM1 1640 (Gibco, Grand Island, NY) containing $10 \%$ heat-inactivated fetal bovine serum (FCS), $2 \times 10^{-3}$ M glutamine, $3 \times 10^{-5} \mathrm{M}$ 2-mercaptoethanol, $12 \mathrm{mM}$ Hepes, and $1 \%$ penicillin/streptomycin (complete media). $5 \mathrm{ml}$ of this suspension was placed on Falcon $100 \times 15$-mm plastic petri dishes and incubated for 1 $\mathrm{h}$ at $37^{\circ} \mathrm{C}$ in $5 \% \mathrm{CO}_{2} / 95 \%$ air. At the end of $1 \mathrm{~h}$, the nonadherent cells were carefully removed and reincubated on a fresh petri dish as above. This was repeated two to three times until surface marker analysis using monoclonal antibody OKM1 (Ortho Pharmaceutical, Raritan, NJ) revealed $<1 \%$ monocytes in preparations used.

Isolation of $T$ cell subsets. To obtain negatively selected $T$ cell subsets, PBMCs or $\mathrm{E}^{+}$cells were incubated for $30 \mathrm{~min}$ at $4^{\circ} \mathrm{C}$ with monoclonal antibody (MAb) OKT8 (Ortho Pharmaceutical) (1 $\mu \mathrm{g}$ antibody $/ 10^{6}$ cells) and with rabbit serum as a source of complement (C) (Cedar Lane Laboratories) for $45 \mathrm{~min}$ at $37^{\circ} \mathrm{C}$; this was repeated (27). The T cells remaining were highly enriched in $\mathrm{T}^{+}$cells $\left(\mathrm{E}^{+} \mathrm{T} 8^{-}\right.$cells). Conversely, $\mathrm{T}^{+}$cells were prepared by treating $\mathrm{E}^{+}$cells with MAb OKT4 plus $\mathrm{C}^{\prime}$ (Ortho Pharmaceutical) (28). After two rounds of antibody and complement treatment, PBMCs were $>98 \%$ depleted of the appropriate cells as judged by indirect immunofluorescence and flow cytometry.

Positively selected $\mathrm{T}$ cell subsets $\left(\mathrm{T}^{+}, \mathrm{T}^{+}\right)$were obtained by staining PBMCs with $1 \mu \mathrm{g}$ of the appropriate antibody per $10^{6}$ cells. Cells were washed and counterstained with fluorescein-conjugated goat antibodies to mouse immunoglobulins. Stained cells were electronically sorted using a modified FACS IV instrument (Becton, Dickinson \& Co., B-D FACS Systems, Sunnyvale, CA). The Epstein-Barr virus-transformed B cell line (EBV-BCL) were derived by incubating $\mathrm{E}^{-}$cells with supernates of the B95-8 virus-producing cell line (29) and cultured in RPMI containing $20 \%$ FCS.

In situ hybridization. Cells were collected and deposited on pretreated glass slides (12) at a concentration of $2-4 \times 10^{4}$ cells/slide with a Shandon cytocentrifuge (Shandon Southern Instruments, Inc., Sewickley, PA). Slides were fixed with phosphate-buffered glutaraldehyde (2-3\%), $\mathrm{pH}$ 7.0, for 3-5 min, rinsed with distilled water and allowed to air dry. After a 30-min treatment at $70^{\circ} \mathrm{C}$ in $300 \mathrm{mM} \mathrm{NaCl} 30 \mathrm{mM} \mathrm{Na}$ citrate, pH 7.0 , slides were incubated for $30 \mathrm{~min}$ at $37^{\circ} \mathrm{C}$ in $20 \mathrm{mM}$ Tris- $\mathrm{HCl}$, pH 7.0. Slides were then incubated for $30 \mathrm{~min}$ at $37^{\circ} \mathrm{C}$ in $20 \mathrm{mM}$ Tris- $\mathrm{HCl}$, $\mathrm{pH} 7.4,2 \mathrm{mM} \mathrm{CaCl}$, and $1 \mu \mathrm{g} / \mathrm{ml}$ proteinase $\mathrm{K}$. They were then washed twice in distilled water, dehydrated through ethanol and allowed to dry. Hybridization buffer contained $50 \%$ formamide, $10 \mathrm{mM}$ Tris- $\mathrm{HCl}$, $\mathrm{pH}$ 7.0, $1 \mathrm{mM}$ EDTA, $600 \mathrm{mM} \mathrm{NaCl}, 1 \times$ Denhardt's solution, $100 \mu \mathrm{l} / \mathrm{ml}$ sonicated salmon sperm DNA $(5 \mathrm{mg} / \mathrm{ml})$, and $2 \%$ dextran sulphate. The probe used to identify sites of Tf mRNA transcription was the full-length coding sequence of human transferrin. It has been described in detail by Yang et al. (10). ${ }^{3} \mathrm{H}$-labeled Tf cDNA (specific activity $2-4 \times 10^{7} \mathrm{cpm} /$ $\mu \mathrm{g}$ DNA) was heat denatured at $100^{\circ} \mathrm{C}$ for $5 \mathrm{~min}$ and rapidly cooled to $0^{\circ} \mathrm{C}$ before adding to hybridization buffer (12). The complete mixture was incubated for $1 \mathrm{~h}$ at $50^{\circ} \mathrm{C}$ before applying to cells. Slides were allowed to hybridize $24 \mathrm{~h}$ under siliconized coverslips in a moist chamber at room temperature. Slides were then washed for 3-4 $\mathrm{h}$ each time in two changes of $4 \times$ standard saline citrate (SSC) $(0.15 \mathrm{M} \mathrm{NaCl}, 0.015 \mathrm{M} \mathrm{Na}$ citrate), two changes of $2 \times \mathrm{SSC}$ for $1 \mathrm{~h}$ each, and $1 \mathrm{~h}$ of $1 \times \mathrm{SSC}$ at $37^{\circ} \mathrm{C}$ Slides were dehydrated in ethanol, allowed to dry thoroughly, and coated with Kodak nuclear track emulsion (NTB-2) (Eastman Kodak Co., Rochester, NY) that had been diluted 1:1 with $0.6 \mathrm{M}$ ammonium acetate Sections were then exposed for $1 \mathrm{wk}$ at $4^{\circ} \mathrm{C}$, developed with D-19, and counterstained with hematoxylin and eosin.

Culture methods. Nonadherent cells were placed in replicate cultures in complete medium containing $10 \%$ fetal bovine serum with $0.05 \%$ phytohemagglutin (PHA) and $20 \mathrm{ng} / \mathrm{ml}$ phorbol myristate acetate. At the indicated times, aliquots of cells were collected and probed with radiolabeled Tf cDNA (10) and IL-2 cDNA (30) clones as described. Transferrin and IL-2 receptor expression was determined by incubating aliquots of cells with monoclonal antibodies 5E9 (31) (tissue culture fluid), or anti-TAC (14) (1:5,000 dilution of ascites fluid), respectively, for $30 \mathrm{~min}$ on ice. Cells were then washed, incubated with fluoresceinated goat anti-mouse immunoglobulin (FGAMIg, Sigma Chemical Co.) and fixed with paraformaldehyde (32). Control aliquots were stained in parallel with FGAMIg alone. Fixed cells were analyzed on a modified FACS IV instrument (Becton, Dickinson \& Co.) equipped with logarithmic amplifiers and utilizing a PDP11-44 computer (Digital Equipment Corp., Marlboro, MA). Percentages of specific staining cells were calculated by comparing integrated histograms of cells stained with appropriate antibody with those of cells stained with FGAMIg only.

Human $\mathrm{T}$ cell clones were isolated from limiting dilution culture by restimulating peripheral blood $\mathrm{E}^{+} \mathrm{T}^{-}$cells with an autologous EBV$\mathrm{BCL}$ in the presence of $2 \%$ by volume of IL-2-containing supernate. The $T$ cell clone bears the cell surface markers $T 3$ and T4, but not T8, and proliferates in response to autologous but not allogeneic EBV-BCL. 2 $\times 10^{4} \mathrm{~T}$ cells and $2 \times 10^{4}$ mitomycin C-treated autologous EBV-BCL were cultured in replicate wells of 96-well round-bottom plates in $\mathbf{0 . 2}$ $\mathrm{ml}$ of complete medium. Cultures were incubated in a humidified $5 \%$ $\mathrm{CO}_{2} / 95 \%$ air atmosphere at $37^{\circ} \mathrm{C}$ for $7 \mathrm{~d}$.

DNA synthesis and IL-2 bioassay. Proliferation was measured by adding $1 \mu \mathrm{Ci}$ of tritiated thymidine $\left[{ }^{3} \mathrm{H}\right] \mathrm{TdR}$ to cultures and harvesting 16-20 h later on filter disks with a Mini-Mash II (M.A. Bioproducts, Walkersville, MD). Triplicate disks were analyzed by liquid scintillation counting and counts averaged. Results are expressed as the mean counts per minute of triplicate cultures \pm standard deviation.

IL-2 production was measured by harvesting $T$ cell supernates by centrifugation and culturing appropriate dilutions of supernates with the IL-2 indicator cell line, CTLL-6 (33). $\left[{ }^{3} \mathrm{H}\right] \mathrm{TdR}$ uptakes were measured and values are expressed as mean counts per minute of triplicate cultures \pm standard deviation.

Serum-free conditions. Cells were placed in culture at $1 \times 10^{5}$ cells/ $\mathrm{ml}$ in $0.2 \mathrm{ml}$ of complete medium or Tf-free medium (Iscove's modified Dulbecco's medium with $0.1 \%$ recrystallized bovine albumin, $20 \mu \mathrm{g} / \mathrm{ml}$ soybean oil, $2 \times 10^{-3} \mathrm{M}$ glutamine, $3 \times 10^{-5} \mathrm{M}$ 2-mercaptoethanol, and antibiotics). Indicated cultures were given $0.1 \%$ PHA-P. $16-20 \mathrm{~h}$ prior to the indicated times, cultures were pulsed with $1 \mu \mathrm{Ci}\left[{ }^{3} \mathrm{H}\right] \mathrm{TdR}$ and then harvested and analyzed as described. Results are expressed as mean counts per minute \pm standard deviation of triplicate cultures.

$\left[{ }^{35}\right.$ S]Methionine immunoprecipitation. Twenty million PBMCs were cultured overnight at $37^{\circ} \mathrm{C}$ in $2.0 \mathrm{ml}$ of complete medium containing $0.1 \%$ PHA-P (Difco, Detroit, MI). Cells were harvested, washed twice in HBSS, and labeled with $2.0 \mathrm{mCi}\left[{ }^{33} \mathrm{~S}\right]$ methionine (Amersham Corp., Arlington Heights, IL) for $6 \mathrm{~h}$ in $1.0 \mathrm{ml}$ of HBSS containing 10\% dialyzed FCS (34). Supernates and cells were harvested by centrifugation. Cells were washed three times in HBSS and lysed in $0.05 \%$ Trixon X-100 in Tris-buffered saline, pH 8.0 (CLB). Supernates and cell lysates were preincubated with $1.0 \mathrm{ml}$ of fixed Staphylococcus aureus (Pansorbin, Calbiochem-Behring Corp., San Diego, CA), which was then discarded. Supernate aliquots $(100 \mu l)$ and cell lysate aliquots $(50 \mu l)$ were then incubated either with $1 \mu \mathrm{l}$ of rabbit antiserum to human Tf (CalbiochemBehring Corp.), $1 \mu \mathrm{l}$ of normal rabbit serum, $100 \mu \mathrm{l}$ of human transferrin solution containing $100 \mu \mathrm{g}$ of unlabeled Tf (Sigma Chemical Co.) plus $2 \mu \mathrm{l}$ of rabbit antiserum to human Tf, $100 \mu \mathrm{l}$ of solution containing 10 $\mu \mathrm{g}$ of human Tf plus $2 \mu \mathrm{l}$ of rabbit antiserum to human Tf, or received no additions. Samples were then maintained $3 \mathrm{~h}$ on ice and immune complexes were collected on $100 \mu \mathrm{l}$ of pelleted Pansorbin. After washing in CLB, bound complexes were eluted by boiling in SDS-polyacrylamide gel electrophoresis (PAGE) reducing sample buffer and run on $10 \%$ discontinuous SDS-PAGE according to the method of Laemmli (35). Gels were fixed, impregnated with fluor (Enhance, New England Nuclear, Boston, MA), dried, and autoradiographed using Kodak X-omat AR5 film (Eastman Kodak Co.). Films were exposed for $3 \mathrm{~d}$ and developed. Molecular weight standards were ${ }^{125} \mathrm{I}$-labeled human Tf $(79.5 \mathrm{kD})$ and bovine albumin $(67 \mathrm{kD})$. 


\section{Results}

Detection of $T f$ mRNA transcription in lymphocytes. Various cell types were examined by in situ hybridization using radiolabeled Tf cDNA. Fig. 1 is a composite of photographs taken after hybridization with the Tf cDNA probe. Occasional cells (2-5\%) having silver grains denoting Tf mRNA hybridization were observed after examination of PBMCs (Fig. $1 A$ ). When peripheral blood $\mathrm{T}$ lymphocytes were isolated by rosette formation with sheep red blood cells, $\sim 10-20 \%$ of the cells contained silver grains, denoting Tf mRNA (Fig. $1 B$ ). No silver grains were observed in non-T cells (Fig. $1 C$ ).

The heterogeneous labeling of $T$ lymphocytes after hybridization with Tf $\mathrm{cDNA}$ suggested that a specific subset of $\mathrm{T}$ lymphocytes was transcribing Tf mRNA. Therefore, $T$ cell subsets defined by monoclonal antibodies OKT3, OKT4, and OKT8 were obtained by indirect immunofluorescence and electronic cell sorting or by antibody plus complement depletion. Isolated $T$ cell subsets were subsequently examined by hybridization with radiolabeled Tf cDNA. Tf mRNA was detected in the OKT3 ${ }^{+}$ and $\mathrm{OKT} 4^{+}$subsets but not in the $\mathrm{OKT} 8^{+}$population (Fig. $1 \mathrm{D}$ and $E$ ). These results were confirmed by examining antibody plus complement-depeleted populations. When $T$ cell populations were depleted of OKT8 cells $\left(\mathrm{OKT}^{-}\right)$, Tf mRNA tran- scription was observed, whereas populations depleted of the $\mathrm{OKT}^{+}$cells demonstrated no hybridization. These data provide evidence that Tf mRNA is transcribed by the $\mathrm{T} 4^{+}$inducer subset.

Expression of $\mathrm{Tf}$ by the inducer subset of $\mathrm{T}$ lymphocytes predicted that human leukemia cells expressing the T4 marker might also transcribe Tf mRNA. Fresh peripheral blood cells from three leukemia patients as well as two malignant cell lines maintained in vitro have been found to transcribe Tf mRNA (Lum et al., manuscript in preparation). One such line, HPBALL, is shown in Fig. $1 F$ with silver grains denoting transcription of Tf mRNA. In contrast, no Tf mRNA transcription was indicated in an EBV-BCL, shown in Fig. $1 G$, indicating that $\mathrm{Tf}$ mRNA expression is not simply a marker of transformation. These results suggest that the Tf $\mathrm{cDNA}$ probe may be useful in combination with MAbs to human lymphocyte surface markers in characterizing heterogeneity of $\mathrm{T}$ cell malignancies.

Tf $m R N A$ expression by activated inducer $T$ cell clones. Because the $T$ cells circulating in peripheral blood are an extremely heterogeneous population, human inducer $\mathrm{T}$ cell clones $\left(\mathrm{T}^{+}\right.$, $\mathrm{T}^{-}$) were utilized to provide a homogeneous population to examine Tf mRNA expression upon activation. Clones that specifically proliferated in response to autologous or allogeneic EBVBCL were examined. The EBV-BCL do not themselves express Tf mRNA as already shown (Fig. $1 G$ ). The $T$ cell clones can
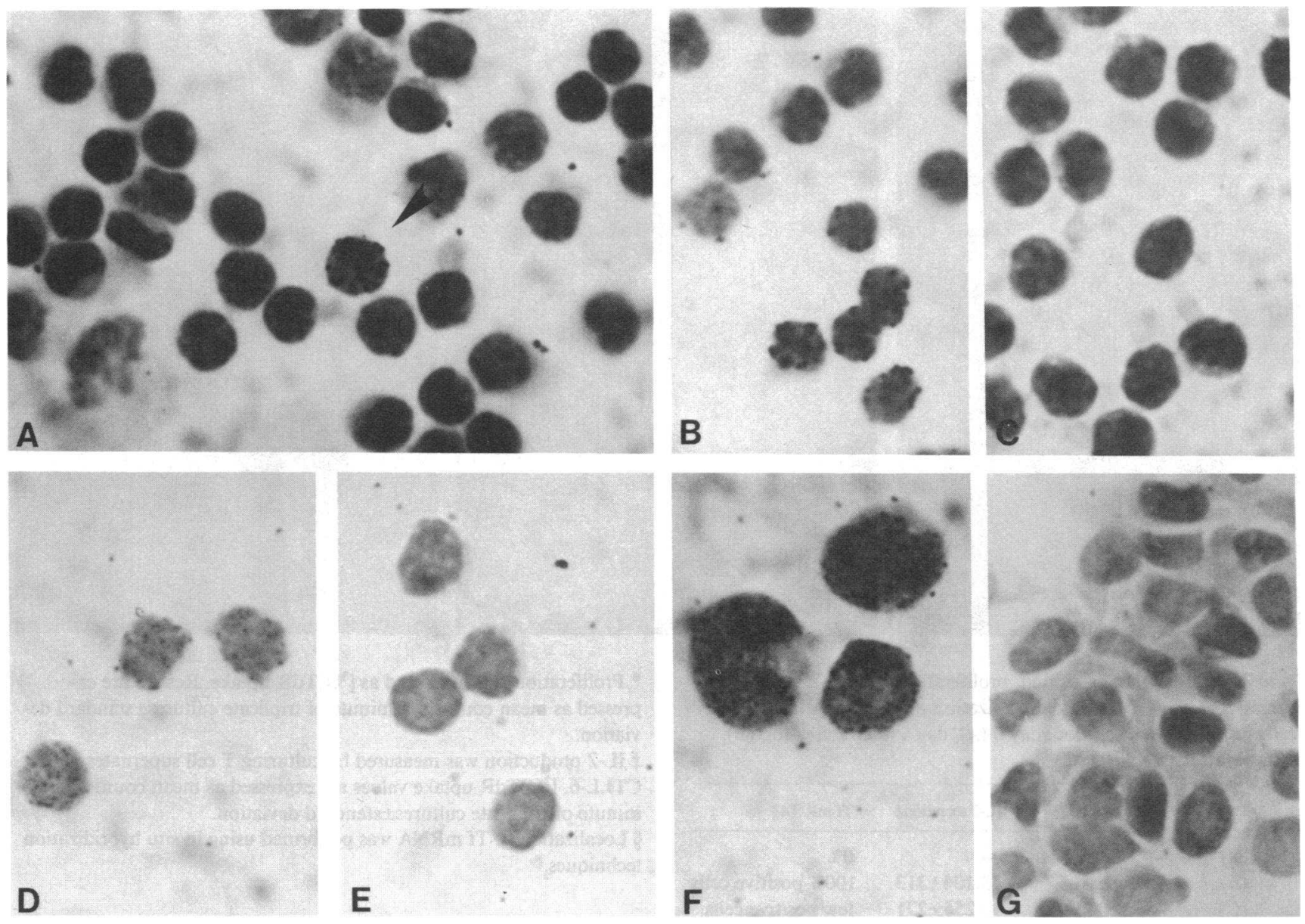

Figure 1. Localization of Tf mRNA in peripheral blood cells using in situ hybridization. (A) PBMCs. (B) T lymphocytes (E-rosette positive). (C) B lymphocytes (E-rosette negative). $(D) \mathrm{OKT}^{+} \mathrm{T}$ cells. $(E) \mathrm{OKT}^{+} \mathrm{T}$ cells. $(F) \mathrm{T}$ cell acute leukemia cell line-HPB-ALL (28). (G) EBV-BCL. 
be induced to undergo repeated rounds of activation at appropriate intervals by adding fresh media and stimulator cells. As shown in Fig. $2 A$, no Tf mRNA was detected in T cells prior to activation. When appropriate stimulator EBV-BCLs were added, IL-2 was secreted, Tf mRNA was transcribed (Fig. 2 B), and proliferation was subsequently induced. As expected, in that the $T$ cells were derived from a single precursor, virtually $100 \%$ of the $T$ cells demonstrated increased levels of Tf mRNA. Note that (a) maximal IL-2 secretion and Tf mRNA expression preceded peak proliferation as measured by $\left[{ }^{3} \mathrm{H}\right] \mathrm{TdR}$ uptake (Fig. 2, appended table) and (b) Tf mRNA transcription was tightly regulated temporally, dropping rapidly to lower levels by $48 \mathrm{~h}$ (Fig. $2 C$ ).

Temporal relationships of expression of $I L-2$ and $T f m R N A$, and $I L-2$ and $T f$ receptors. Previous studies indicated that the binding of IL-2 to its cell surface receptor preceded and was required for $\mathrm{Tf}$ receptor expression (18). In the next series of experiments, attention was focused on the temporal relationship of Tf mRNA transcription with reference to the induction of IL-2 mRNA and the appearance of IL-2 and Tf receptors. Although the temporal order of expression of Tf, IL-2, and their respective receptors is measured by both immunologic and DNA hybridization techniques and, therefore, may not be highly definitive, these experiments have provided evidence of the series of events preceding lymphocyte proliferation. The results are summarized in Table $I$.

IL-2 mRNA was first observed in peripheral blood lymphocytes at $6 \mathrm{~h}$ after mitogen activation and could still be detected at $24 \mathrm{~h}$ after activation. Tf mRNA, however, was not observed until $12 \mathrm{~h}$ after activation; it peaked at $24 \mathrm{~h}$ and was still detectable as late as $48 \mathrm{~h}$ after activation. Analysis of cell surface receptors for IL-2 and Tf using indirect immunofluorescence and flow cytometry indicated that IL-2 receptors appeared first, increased in numbers, and were followed by an increase in Tf receptors. Alternately, the rate of increase of $\mathrm{Tf}$ receptors could be slower. Levels of both Tf and IL-2 receptors peaked at $48 \mathrm{~h}$ after activation, which coincided with the peak observed in proliferative activity. Therefore, these results are consistent with those previously reported $(18,20,36)$ in which IL-2 production is followed by the appearance of IL-2, and then Tf receptors. We have demonstrated that the induction of Tf mRNA transcription seems to be an intermediate event along the IL-2dependent activation pathway in $T$ lymphocytes. Tf mRNA expression occurs after IL-2 mRNA induction but prior to
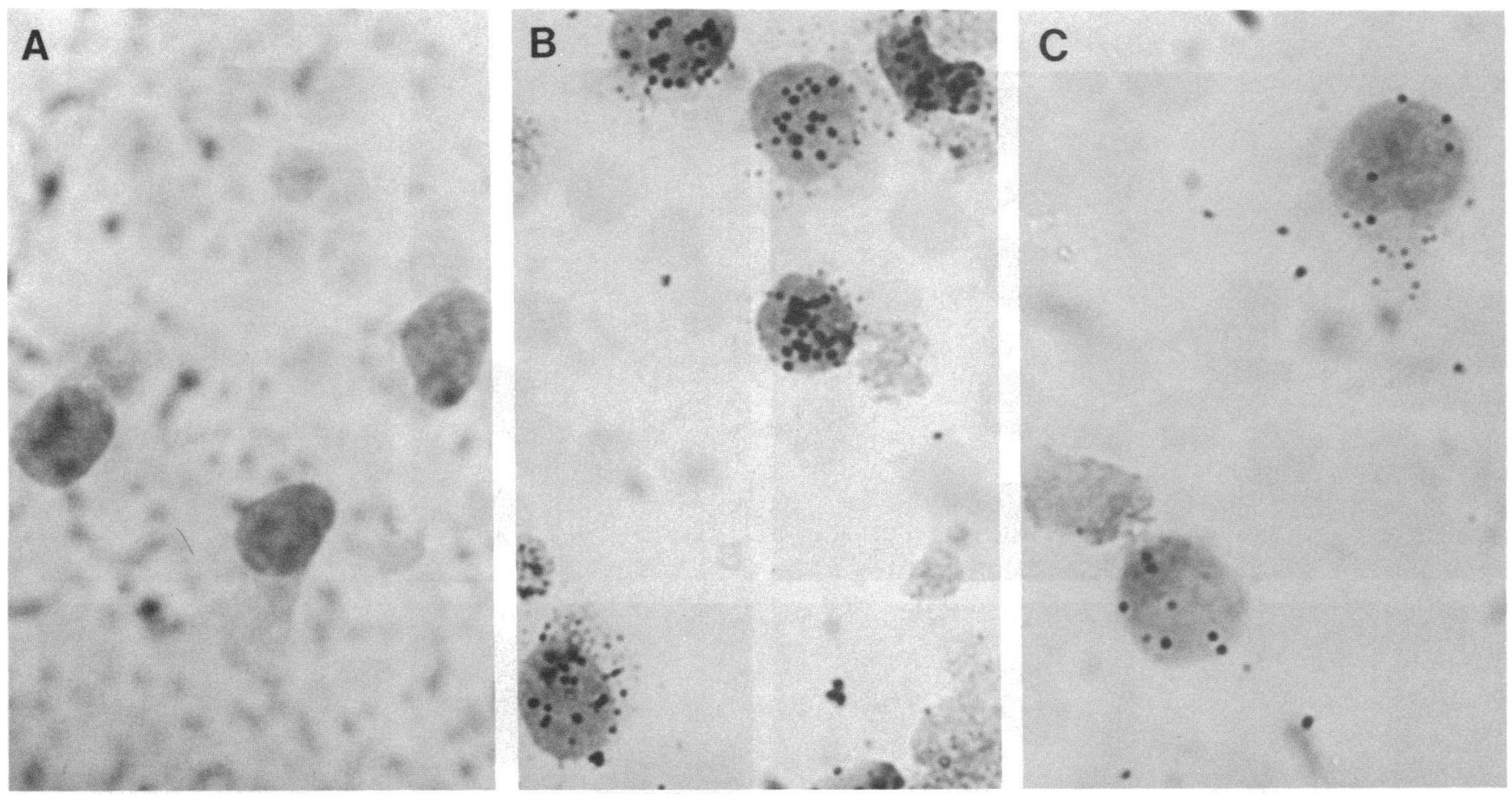

Figure 2. Tf mRNA transcription, proliferation, and IL-2 secretion by a human $\mathrm{T}^{+}{ }^{+} 8^{-} \mathrm{T}$ cell clone. Localization of $\mathrm{Tf} \mathrm{mRNA}$ in $\mathrm{T} 4^{+} \mathrm{T}^{-}$ $T$ cell clones before activation, day $0(A)$, day 1 after activation $(B)$, and day 2 after activation $(C)$.

\begin{tabular}{llcrl}
\hline Day & Panel & Proliferation* $^{*}$ & IL-2 secretion & Tf mRNA§ \\
\hline 0 & $(A)$ & - & - & $0 \%$ \\
1 & $(B)$ & $998 \pm 61$ & $13,104 \pm 313$ & $100 \%$ positive cells \\
2 & $(C)$ & $27,393 \pm 1,057$ & $10,255 \pm 271$ & few positive cells \\
4 & & $25,826 \pm 2,401$ & $7,731 \pm 198$ & $0 \%$ \\
7 & & $2,321 \pm 103$ & $4,329 \pm 123$ & $0 \%$
\end{tabular}

* Proliferation was measured as $\left[{ }^{3} \mathrm{H}\right] \mathrm{TdR}$ uptake. Results are expressed as mean counts per minute of triplicate cultures \pm standard deviation.

¥IL-2 production was measured by culturing $T$ cell supernates with CTLL-6. $\left[{ }^{3} \mathrm{H}\right] \mathrm{TdR}$ uptake values are expressed as mean counts per minute of triplicate cultures \pm standard deviation. $\S$ Localization of Tf mRNA was performed using in situ hybridization techniques. 
Table I. Detection of Transferrin mRNA, Transferrin

Receptor, Interleukin $2 \mathrm{mRNA}$ and Interleukin 2 Receptor at Periods after Activation of Peripheral Blood Cells*

\begin{tabular}{|c|c|c|c|c|c|}
\hline & \multicolumn{5}{|c|}{ Time after activation } \\
\hline & 0 & 6 & 12 & 24 & 48 \\
\hline & $h$ & & & & \\
\hline Transferrin mRNA & - & - & + & ++ & + \\
\hline Interleukin 2 mRNAł & - & ++ & + & + & - \\
\hline Transferrin receptor§ & $2 \%$ & $9 \%$ & $17 \%$ & $21 \%$ & $84 \%$ \\
\hline Interleukin 2 receptor§ & $3 \%$ & $26 \%$ & $29 \%$ & $49 \%$ & $92 \%$ \\
\hline
\end{tabular}

* 10 random microscope fields were counted for labeling cells. Each field contained 10-20 cells total. Experimental slides were performed in triplicate. The number of cells scoring positive were an average of the 10 fields per slide. Detection of $>10$ grains/cell $(++),<10$ grains/ cell $(+)$, and no grains located/cell ( - ).

¥ Localization of mRNA was performed using in situ hybridization. $\S$ Transferrin receptor and IL-2 receptor were detected using MAbs 5E9 and anti-TAC, respectively. Cells were then stained with FGAMIg and analyzed by flow cytometry.

expression of IL-2 and Tf receptors. DNA synthesis then follows the growth factor and specific receptor events.

Activated PBMCs synthesize Tf. To demonstrate that $\mathrm{Tf}$ mRNA detection was associated with synthesis of Tf protein, PBMCs were activated with (PHA) and radiolabeled with $\left[{ }^{35} \mathrm{~S}\right]$ methionine. Supernates and cell lysates were immunoprecipitated with rabbit antiserum to human $\mathrm{Tf}$ and analyzed by SDS-PAGE under reducing conditions (Fig. 3). As demonstrated in lanes 1 and 7 , both the supernate and cell lysate contained immunoreactive radiolabeled material giving a molecular weight band similar to human Tf $(79,500 \mathrm{D}$, lane 6$)$. This band was not seen when nonimmune serum was used (lanes 2 and 8 ) or when antiserum was omitted (lane 3). Furthermore, the appearance of this band was specifically inhibited when unlabeled human $\mathrm{Tf}$ was added to the supernates in a competition experiment (lanes 4 and 5).

To obtain an approximation of the amount of $\mathrm{Tf}$ protein present in the supernatant, densitometer scans of lanes 1,4 , and 5 were performed (Fig. 3 B). A Tf concentration of between 1 and $5 \mu \mathrm{g} / \mathrm{ml}$ seemed to be present in the supernate as calculated from the area beneath the peaks and amount of unlabeled $\mathrm{Tf}$ used in competition.

A second band, at $\sim 62 \mathrm{kD}$, was also seen in lanes containing samples immunoprecipitated with rabbit anti-Tf serum. This band also showed a decrease in intensity when "cold" Tf was added (Fig. $3 A$, lanes 4 and 5; Fig. $3 B$, lines $b$ and $c$ ). Because the molecular weight of the Tf polypeptide backbone is predicted to be at least $75,157 \mathrm{D}(10)$, the band does not appear to correspond to a nonglycosylated or partially glycosylated form of Tf. The precise characterization of the $62-\mathrm{kD}$ Tf derivative secreted by lymphocytes awaits further results.

From the experiments described above, we can postulate that the Tf mRNA expression in human peripheral $\mathrm{T}^{+}$inducer cells leads to the synthesis and secretion of $\mathrm{Tf}$ protein. Our studies appear to confirm previous reports suggesting the synthesis and secretion of $\mathrm{Tf}$ by lymphocytes $(23,24)$. Immunofluorescent localization of $\mathrm{Tf}$ in $\mathrm{T}$ cells was associated with "halo" formation,
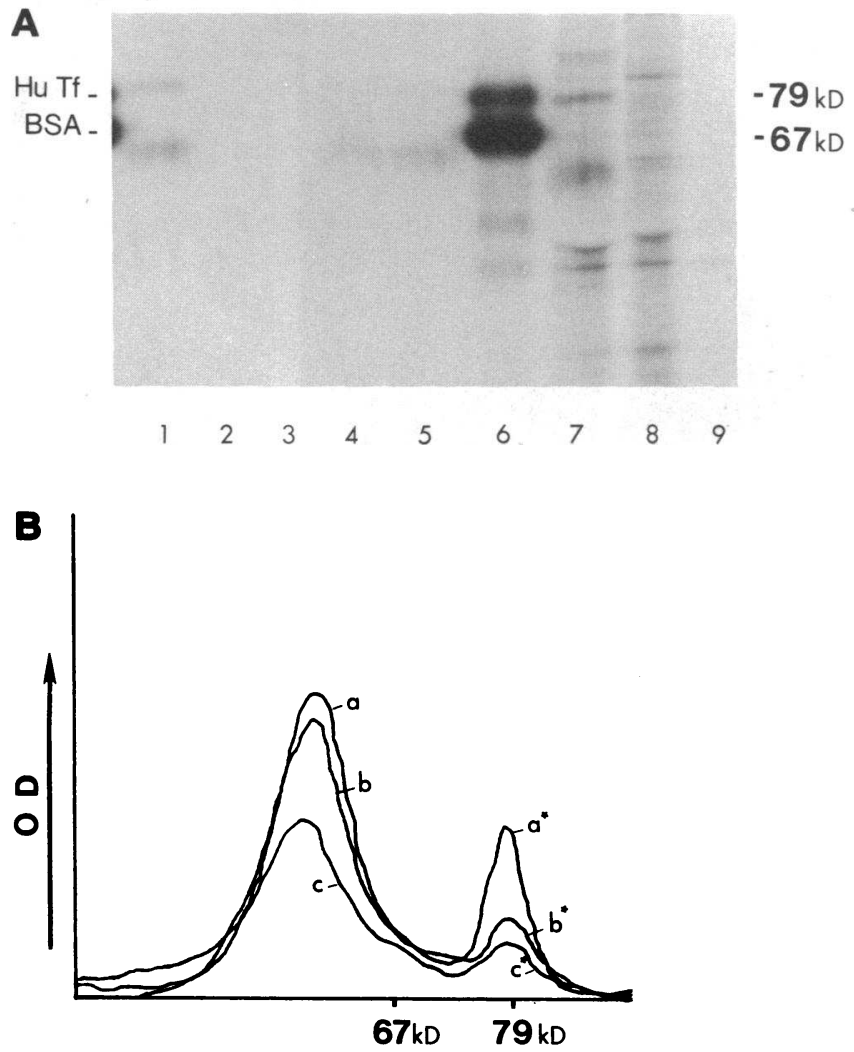

Figure 3. Immunoprecipitation of $\left[{ }^{35} \mathrm{~S}\right] \mathrm{methionine}$ radiolabeled proteins from supernates and cell extracts of PHA-activated human PBMCs. (A) Autoradiograph of SDS polyacrylamide gel Tf antiserum (lanes 1 and 7), normal rabbit serum (lanes 2 and 8 ), and none (lanes 3 and 9). Lanes 1-5 contain cell supernatants while lanes 7-9 contain cell lysates. Competition with cold Tf (lanes 4 and 5). ${ }^{125} \mathrm{I}$-labeled Tf and albumin standards (lane 6$)$. (B) Densitometer scans of lanes $1(a)$, $4(c)$, and $5(b)$. Asterisks indicate peaks that migrate identically with authentic human Tf.

suggesting Tf secretion (24). Other studies showed the association of radiolabeled immunoreactive Tf with cell extracts of PBMCs, although the molecular weight was not determined (23). Previous results taken together with the biochemical data of Fig. $3 \mathrm{~A}$ and $B$, provide evidence for the translation of Tf mRNA into Tf protein and its release by inducer $\mathrm{T}$ lymphocytes.

Tf synthesis in serum-free, Tf-free media. Although exogenous Tf has been shown to be an essential growth factor (4-8, 37-40), the ability of a small percentage of lymphocytes to continue to proliferate under certain serum-free conditions is consistent with the possibility that they may be synthesizing their own transferrin (38). To examine this, PBMCs were cultured in serum-free, Tf-free medium with and without PHA at high cell density. Results are summarized in Fig. 4. There was no difference in background proliferation of cells in complete medium compared to Tf-free medium when PHA was omitted. With the addition of PHA, cells grown in complete medium proliferated as expected, with a significant increase in $\left[{ }^{3} \mathrm{H}\right] \mathrm{TdR}$ incorporation. Cells grown in Tf-free medium responded to PHA with an increase in proliferation. The magnitude of the responses observed in Tf-free medium was $25-30 \%$ of that seen in complete medium. To determine how many cells in the population were actually synthesizing Tf, aliquots of cells grown in each of the culture 

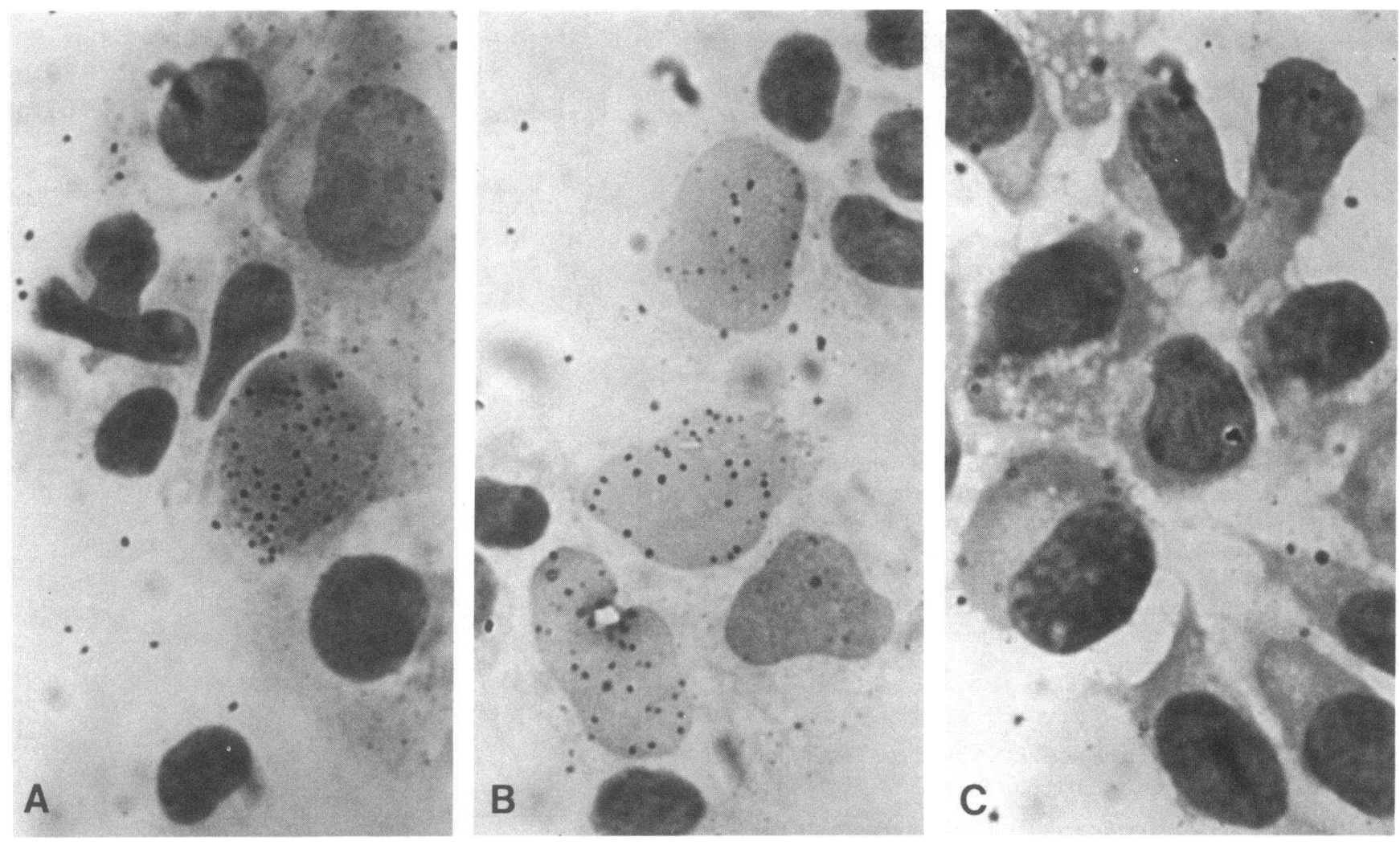

Figure 4. Proliferation of PHA-activated peripheral blood cells in Tf-free medium. Localization of Tf mRNA in cells cultured in Tf-free media with $0.1 \%$ PHA on day $1(A)$, day $2(B)$, and day $4(C) .10$ random microscope fields were counted for labeling cells. Each field contained at least 10-20 cells total. Labeling cells were scored positive which had $>10$ silver grains. Estimated percentages of positively labeling cells are an average of 10 fields of three separate slides.

\begin{tabular}{llll}
\hline Culture media & Day 1 & Day 2 & \multicolumn{1}{l}{ Day 4 } \\
\hline & $c p m$ & $c p m$ & \multicolumn{1}{c}{$c p m$} \\
Complete media & $1,919 \pm 533$ & $1,517 \pm 142$ & $3,313 \pm 412$
\end{tabular}

conditions were hybridized to Tf cDNA (see Fig. $4 A-C$ ). On day 1 , a small percentage of the cells, $\sim 5-10 \%$, were found to transcribe Tf mRNA. By day 2, the cellular percentage had increased to $15-20 \%$. However, by day 4 , the hybridization signal had dropped to almost undetectable levels and scattered clusters of blastlike cells were observed as shown in Fig. $4 \mathrm{C}$. These results clearly indicate that under defined culture conditions (lacking exogenous Tf), a small percentage of cells synthesized Tf, which supported a significant amount of cellular proliferation.

\section{Discussion}

We report here the specific localization of Tf synthesis in $\mathrm{T}^{+}$ inducer $\mathrm{T}$ lymphocytes. Tf mRNA was localized to $\mathrm{T}^{+}$cells isolated by positive and negative selection procedures as well as using isolated $\mathrm{T}^{+} \mathrm{T}^{-}$clones. In activated cells, the Tf mRNA was translated into radiolabeled, immunoreactive $\mathrm{Tf}$ that was then secreted into culture supernates. These results confirm and extend previous studies suggesting that $\mathrm{Tf}$ is synthesized and released from peripheral blood $T$ cells $(23,24,41)$. The results

\begin{tabular}{llcc}
\hline Culture media & Day 1 & Day 2 & Day 4 \\
\hline $\begin{array}{c}\text { Complete media } \\
\quad+0.1 \% \text { PHA }\end{array}$ & $6,053 \pm 188$ & $71,201 \pm 280$ & $192,810 \pm 760$ \\
$\begin{array}{c}\text { Tf-free media } \\
\text { Tf-free media } \\
+0.1 \% \text { PHA }\end{array}$ & $1,844 \pm 898$ & $1,547 \pm 75$ & $2,402 \pm 99$ \\
& $4,970 \pm 202$ & $21,168 \pm 114$ & $40,019 \pm 205$ \\
\hline
\end{tabular}

Results are expressed as mean counts per minute of triplicate cultures \pm standard deviation.

described here are in contrast, however, to studies indicating the release of $\mathrm{Tf}$ from $\mathrm{OKT} 8^{+}$cells but not $\mathrm{OKT} 4^{+}$cells $(41)$. The reasons for this apparent discrepancy are not entirely clear. The study of Broxmeyer et al. (41) utilized immunodetection and a bioassay of released $\mathrm{Tf}$ that did not directly assess the site of $\mathrm{Tf}$ synthesis. Therefore, the uptake of preformed $\mathrm{Tf}$ by $\mathrm{T}^{+}$cells and its subsequent release may be the basis of those observations and may represent another important regulatory mechanism.

The term "autocrine" has been used to describe self-stimulation processes of a cell producing a growth promoting factor and its specific membrane receptor $(42,43)$. Autocrine growth regulation was initially proposed as a possible mechanism leading to malignant transformation and was studied in several tumor cell systems (44-46). Recently, further investigations of autocrine growth factors and malignancy have been described (47-49). In contrast to these studies autocrine mechanisms may confer selective growth advantages to rapidly proliferating normal cell populations. At present, there are two known instances, one in human trophoblasts $(50,51)$ and two in rat smooth muscle cells (52), suggesting that autocrine regulation of cell growth may be 


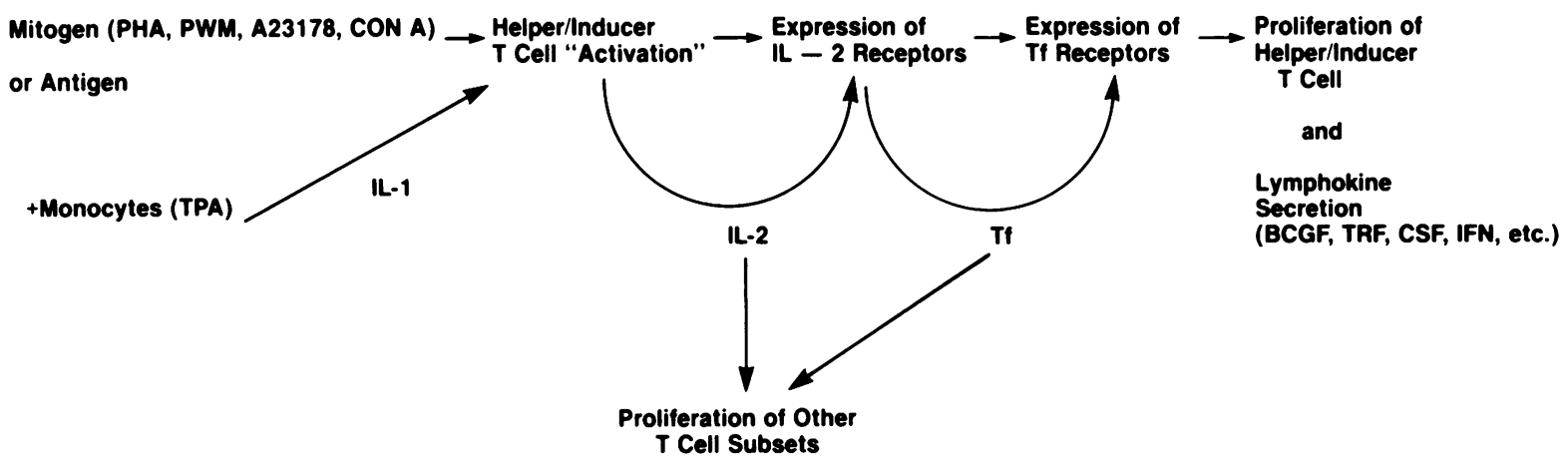

Figure 5. Proposed role of Tf transferrin synthesis by helper/inducer $\mathrm{T}$ cells in $\mathrm{T}$ cell activation. Additional abbreviations used in this figure: PWM, pokeweed mitogen; CON A, concanavalin A; TPA, 12-O-tetracanoylphorbol 13-acetate; BCGF, B cell growth factor; TRF, $T$ cell replacing factor; CSF, colony-stimulating factor; IFN, $\gamma$-interferon.

a common control mechanism in early embryonic development. We present evidence here suggesting an additional normal regulatory autocrine loop involving $\mathrm{Tf}$ and $\mathrm{Tf}$ receptor which is linked to the IL-2/IL-2 receptor autocrine pathway (53).

A diagram of the role of transferrin synthesis by inducer $T$ cells in $\mathrm{T}$ lymphocyte activation and proliferation is illustrated in Fig. 5. Macrophage/monocyte accessory cells are activated by antigen to produce interleukin 1 (IL-1), which in turn activates specific $T$ cells to synthesize IL- 2 . In vitro $T$ cells can be directly activated with mitogens such as PHA or concanavalin A and phorbal esters which serve to substitute for the action of IL-1. The secretion of IL-2 has then been shown to be closely followed by the induction of IL- 2 receptors and Tf receptors. In the presence of $\mathrm{Tf}$ the inducer $\mathrm{T}$ cells themselves proliferate. The transcription of Tf mRNA has been shown here to occur after the onset of IL-2 mRNA transcription but prior to IL-2 and Tf receptor expression. It is of interest that $\mathrm{Tf}$ is synthesized by the same $\mathrm{T}$ lymphocyte subset found to be the major source of IL2. Thus, the inducer $T$ cell may be an important source of a number of growth factors required by activated lymphocytes within various other subsets.

The demonstration of a second autocrine pathway in $\mathrm{T}$ cell proliferation has far-reaching implications. That the transferrin loop is under the control of the IL-2 autocrine mechanism has been demonstrated by blocking $\mathrm{Tf}$ receptor expression by the action of anti-TAC, which specifically interacts with the IL-2 receptor (18). We are currently investigating whether or not the interruption of the IL-2 signal has an effect on Tf mRNA transcription. It may be significant that Tf mRNA transcription lags behind IL-2 mRNA appearance by several hours, thus providing an interval in which further regulation is possible. The synthesis of transferrin and its receptor during normal $\mathrm{T}$ cell proliferation suggests a role of this autocrine pathway in malignant $T$ cell proliferation. We have found Tf mRNA in a number of $\mathrm{T}$ cell lines, including HPB-ALL, a $\mathrm{T}^{+}$cell leukemic line which also expresses $\mathrm{Tf}$ receptors (28).

Withholding iron is characteristic of host defense mechanisms against microbial pathogens and neoplasia (54-57). Microbial growth is severely reduced with restricted iron concentrations, an effect that is readily reversed by adding exogenous iron or iron-saturated $\operatorname{Tf}(58,59)$. The importance of this phenomenon is particularly well illustrated by reports in which therapeutic iron supplementation was associated with increased morbidity and mortality from tuberculosis, brucellosis, malaria, and sepsis $(55,56)$. The ability to enhance the virulence of in- fections and neoplasia is unique to iron and has not been observed with other trace metals (57). To evade the difficulty of obtaining iron, bacteria and neoplastic cells have been reported to produce their own low molecular weight iron-binding proteins called siderophores and growth factors capable of binding iron $(19,60)$. Exact mechanisms by which serum iron is decreased and redistributed to tissue storage sites are not yet fully defined. However, the immune system requires the delivery of Tf-bound iron for proper lymphocyte function $(8,61,62)$. Therefore, during situations when iron is being withheld from the circulation, the capability of a specific subset of human $T$ lymphocytes to synthesize transferrin may provide a source of available iron to support localized proliferation of lymphocytes required in the host's immune response.

\section{Acknowledgments}

We thank Dr. John Hutton, Children's Hospital Medical Center, Cincinnati, OH, for the HPB-ALL cell line; Dr. T. Taniguchi, Japanese Foundation for Cancer Research, Tokyo, Japan, for IL-2 cDNA (p316); Dr. T. Waldmann, NCI, Bethesda, Maryland, for the IL-2 monoclonal antibody (anti-TAC); Charles A. Thomas, The University of Texas Health Science Center at San Antonio, for FACS analysis; Betty Russell, Judith Pride, and Dalia Garcia for manuscript preparation; and Lonnie Pleasant for laboratory assistance.

This work was supported by grants AM-34130, HD-16584, and GM33298 from the National Institutes of Health and American Cancer Society grant NP-470. A. J. Infante is a fellow of the John A. Hartford Foundation.

\section{References}

1. Putnam, F. W. 1975. Transferrin. In The Plasma Proteins; Structure, Function and Genetic Control. F. W. Putnam, editor. Academic Press, Inc., New York. 265-316.

2. MacGillivray, R. T. A., E. Mendez, S. K. Sinha, M. R. Sutton, J. Lineback-Zins, and K. Brew. 1982. The complete amino acid sequence of human serum transferrin. Proc. Natl. Acad. Sci. USA. 79:2504-2508.

3. Aisen, P., and I. Listowsky. 1980. Iron transport and storage proteins. Annu. Rev. Biochem. 49:357-393.

4. Tormey, D. C., R. C. Imrie, and C. C. Mueller. 1972. Identification of transferrin as a lymphocyte growth promoter in human serum. Exp. Cell. Res. 74:163-169.

5. Iscove, N. N., and F. Melchers. 1978. Complete replacement of serum by albumin, transferrin and soybean lipid in cultures of lipopolysaccharide-reactive B lymphocytes. J. Exp. Med. 147:923-927.

6. Dillner-Centerlind, M. L., S. Hammarstrom, and P. Perlmann. 
1979. Transferrin can replace serum for in vitro growth of mitogenstimulated T-lymphocytes. Eur. J. Immunol. 9:942-948.

7. Barnes, D., and G. Sato. 1980. Methods for growth of cultured cells in serum-free medium. Anal. Biochem. 102:255-270.

8. Brock, J. H., and T. Mainou-Fowler. 1983. The role of iron and transferrin in lymphocyte transformation. Immunol. Today. 4:347-351.

9. Newman, R., C. Schneider, R. Sutherland, L. Vodinelich and M. Greaves. 1982. The transferrin receptor. Trends Biochem. Sci. 7:397400.

10. Yang, F., J. B. Lum, J. R. McGill, C. M. Moore, S. L. Naylor, P. H. van Bragt, W. D. Baldwin, and B. H. Bowman. 1984. Human transferrin: cDNA characterization and chromosomal location. Proc. Natl. Acad. Sci. USA. 81:2752-2756.

11. Lum, J. B., A. J. Infante, and B. H. Bowman. 1985. In situ hybridization: location of plasma protein transcription. In Protides of the Biological Fluids. H. Peeters, editor. Pergamon Press, Oxford, England. 87-90.

12. Lum, J. B. Visualization of mRNA transcription of specific genes in human cells and tissues using in situ hybridization. BioTechniques. In press.

13. Robb, R. J., A. Munck, and K. A. Smith. 1981. T cell growth factor receptors. J. Exp. Med. 154:1455-1474.

14. Leonard, W. J., J. M. Depper, T. Uchijama, K. A. Smith, T. A. Waldmann, and W. C. Greene. 1982. A monoclonal antibody that appears to recognize the receptor for human T-cell growth factor: partial characterization of the receptor. Nature (Lond.). 300:267-271.

15. Ruscetti, F. W., D. A. Morgan, and R. C. Gallo. 1977. Functional and morphologic characterization of human $\mathrm{T}$ cells continuously grown in vitro. J. Immunol. 119:131-138.

16. Gillis, S., and K. A. Smith. 1977. Long term culture of tumourspecific cytotoxic T cells. Nature (Lond.). 268:154-156.

17. Larrick, J. W., and P. Cresswell. 1979. Transferrin receptors on human B and T lymphoblastoid cell lines. Biochim. Biophys. Acta. 583: 483-490.

18. Neckers, L. M., and J. Cossman. 1983. Tf receptor induction in mitogen-stimulated human T-lymphocytes is required for DNA synthesis and cell division is regulated by interleukin 2. Proc. Natl. Acad. Sci. USA. 80:3494-3498.

19. Trowbridge, I. S., and M. B. Omary. 1981. Human cell surface glycoprotein related to cell proliferation is the receptor for transferrin. Proc. Natl. Acad. Sci. USA. 78:3039-3043.

20. Cantrell, D. A., and K. A. Smith. 1984. The interleukin-2 T-cell system: a new cell growth model. Science (Wash. DC). 224:1312-1316.

21. Reinherz, E. L., P. C. Kung, G. Goldstein, and S. Schlossman. 1979. Separation of functional subsets of human T cells by a monoclonal antibody. Proc. Natl. Acad. Sci. USA. 76:4061-4065.

22. Reinherz, E. L., P. C. Kung, J. M. Breard, G. Goldstein, and S. F. Schlossman. 1980. T cell requirements for generation of helper factor(s) in man: analysis of the subsets involved. J. Immunol. 124:18831887.

23. Soltys, H. D., and J. I. Brody. 1970. Synthesis of transferrin by human peripheral blood lymphocytes. J. Lab. Clin. Med. 75:250-257.

24. Nishiya, K., J. W. Chiao, and M. DeSousa. 1980. Iron binding proteins in selected human peripheral blood cell sets: immunofluorescence. Br. J. Haematol. 46:235-245.

25. Boyum, A. 1969. Separation of leukocytes from blood and bone marrow. Scand. J. Clin. Invest. 21(Suppl.):137.

26. Mendes, N. F., M. E. A. Tolnai, N. P. A. Silveira, R. B. Gilbertsen, and R. S. Metegar. 1973. Technical aspects of the rosette tests used to detect human complement receptor (B) and sheep erythrocyte-binding (T) lymphocytes. J. Immunol. 111:860-867.

27. Romain, P. L., C. Morimoto, J. F. Daley, L. S. Palley, E. L. Reinherz, and S. F. Schlossman. 1984. Reactivity of inducer cell subsets and $\mathrm{T}_{8}$-cell activation during the human autologous mixed lymphocyte reaction. Clin. Immunol. Immunopathol. 30:117-128.

28. Morikawa, K., E. Tatsumi, M. Baba, T. Harada, and K. Yasuhira.
1978. Two E-rosette-forming lymphoid cell lines. Int. J. Cancer. 21:166171.

29. Miller, G., and M. Lipman. 1973. Release of infectious EpsteinBarr virus by transformed marmoset leukocytes. Proc. Natl. Acad. Sci. USA. 70:190-194.

30. Taniguchi, T., H. Matsui, T. Fujita, C. Takaoka, N. Kashima, R. Yoshimoto, and J. Hamuro. 1983. Structure and expression of a cloned cDNA for human interleukin-2. Nature (Lond.). 302:305-310.

31. Haynes, B. F., M. Hemler, T. Cotner, D. L. Mann, G. S. Eisenbarth, J. L. Strominger, and A. S. Fauci. 1981. Characterization of a monoclonal antibody (5E9) that defines a human cell surface antigen of cell activation. J. Immunol. 127:347-351.

32. Lanier, L. L., and N. L. Warner. 1981. Paraformaldehyde fixation of hematopoetic cells for quantitative flow cytometry (FACS) analysis. J. Immunol. Methods. 47:25-30.

33. Rosenberg, S. A. 1982. Potential use of expanded T lymphoid cells and $\mathrm{T}$ cell clones for the immunotherapy of cancer. In Isolation, Characterization and Utilization of T Lymphocyte Clones. C. G. Fathman and F. W. Fitch, editors. Academic Press, Inc., New York. 451-466.

34. McMillan, M., J. A. Frelinger, P. P. Jones, D. B. Murphy, H. O. McDevitt, and L. Hood. 1980. Structure of murine Ia antigens. J. Exp. Med. 153:936-950.

35. Laemmli, U. K. 1970. Cleavage of structural proteins during assembly of the head of bacteriophage T4. Nature (Lond.). 227:680-685.

36. Cantrell, D. A., and K. A. Smith. 1983. Transient expression of interleukin-2 receptors: Consequences for T cell growth. J. Exp. Med. 158:1895-1911.

37. Sachs, L. 1978. Control of cloning of normal human T lymphocytes by transferrin, albumin and different lectins. Clin. Exp. Immunol. 33:495-498.

38. Imrie, R. C., and G. C. Mueller. 1968. Release of a lymphocyte growth promotor in leukocyte cultures. Nature (Lond.). 219:1277-1279.

39. Tormey, D. C., R. C. Imrie, and G. C. Mueller. 1972. Identification of transferrin as a lymphocyte growth promoter in human serum. Exp. Cell. Res. 74:163-169.

40. Tormey, D. C., and G. C. Mueller. 1972. Biological effects of transferrin on human lymphocytes in vitro. Exp. Cell. Res. 74:220-226.

41. Broxmeyer, H. E., L. Lu, and J. Bognacki. 1983. Transferrin derived from an $\mathrm{OKT}^{-}$positive subpopulation of $\mathrm{T}$ lymphocytes suppresses the production of granulocyte-macrophage colony-stimulatory factors from mitogen-activated T-lymphocytes. Blood. 62:37-50.

42. Temin, H. M. 1970. Control of multiplication of uninfected rat cells and rat cells converted by murine sarcoma virus. J. Cell. Physiol. 75:107-120.

43. Sporn, M. B., and G. J. Todaro. 1980. Autocrine secretion and malignant transformation of cells. N. Engl. J. Med. 303:878-880.

44. Todaro, G. J., J. E. DeLarco, and S. Cohen. 1976. Transformation by murine and feline sarcoma viruses specifically blocks binding of epidermal growth factor. Nature (Lond.). 264:26-31.

45. DeLarco, J. E., and G. J. Todaro. 1978. Growth factors from murine sarcoma virus-transformed cells. Proc. Natl. Acad. Sci. USA. 75: 4001-4005.

46. Heldin, C. H., and B. Westermark. 1984. Growth factors: Mechanism of action and relation to oncogenes. Cell. 37:9-20.

47. Van Zoelen, E. J. J., D. R. Twardzik, T. M. J. van Oostwaard, P. T. van der Saag, S. E. de Laat, and G. J. Todaro. 1984. Neuroblastoma cells produce transforming growth factors during exponential growth in a defined hormone-free medium. Proc. Natl. Acad. Sci. USA. 81:40854089.

48. Betsholtz, C., C.-H. Heldin, M. Nister, B. Ek, A. Wasteson, and B. Westermark. 1983. Synthesis of a PDGF-like growth factor in human glioma and sarcoma cells suggests the expression of the cellular homolog of the transforming protein of simian sarcoma virus. Biochem. Biophys. Res. Commun. 117:176-182.

49. Owen, A. J., P. Pantazis, and H. N. Antoniades. 1984. Simian sarcoma virus-transformed cells secrete a mitogen identical to plateletderived growth factor. Science (Wash. DC). 225:54-56. 
50. Pfeifer-Ohlsson, S., A. S. Goustin, J. Rydnert, L. Bjersing, T. Wahlström, D. Stehelin, and R. Ohlsson. 1984. Spatial and temporal pattern of cellular myc oncogene expression in developing human placenta: implications for embryonic cell proliferation. Cell. 38:585-596.

51. Gouslin, A. S., G. Betsholtz, S. Pfeifer-Ohlsson, H. Persson, J. Rydnert, M. Bywater, G. Holmgren, C. Heldin, B. Westermark, and R. Ohlsson. 1985. Co-expression of the sis and myc proto-oncogens in developing human placenta suggests autocrine control of trophoblast growth. Cell. 41:301-312.

52. Seifert, R. A., S. M. Schwartz, and D. F. Bowen-Pope. 1984. Developmentally regulated production of platelet-derived growth factorlike molecules. Nature (Lond.). 311:669-671.

53. Meuer, S. C., R. E. Hussey, D. A. Cantrell, J. C. Hodgdon, S. F. Schlossman, K. A. Smith, and E. L. Reinberg. 1984. Triggering of the $\mathrm{T} 3-\mathrm{Ti}$ antigen-receptor complex results in clonal T-cell proliferation through an interleukin 2-dependent autocrine pathway. Proc. Natl. Acad. Sci. USA. 81:1509-1513.

54. Ballantyne, G. H. 1984. Rapid drop in serum iron concentration as a host defense mechanism: a review of experimental and clinical evidence. Am. Surg. 50:405-411.
55. Dinarello, C. A. 1984. Interleukin-1 and the pathogenesis of the acute phase response. $N$. Engl. J. Med. 311:1413-1418.

56. Weinberg, E. D. 1984. Iron withholding: a defense against infection and neoplasia. Physiol. Rev. 64:65-102.

57. Letendre, E. D. 1985. The importance of iron in the pathogenesis of infection and neoplasia. Trends Biochem. Sci. 9:166-168.

58. Murray, M. J., A. B. Murray, M. B. Murray, and C. J. Murray. 1978. The adverse effect of iron repletion on the course of certain infections. Br. Med. J. 2:1113-1115.

59. Hunter, R. L., B. Bennett, M. Towns, and W. R. Vogler. 1984. Transferrin in Disease II: Defects in the regulation of transferrin saturation with iron contribute to susceptibility to infection. Am. J. Clin. Pathol. 81:748-753.

60. Fernandez-Pol, J. A. 1983. Siderophore-like growth factor synthesis by transformed cells. Microbiology. 1983:313-317.

61. Brock, J. H. 1981. The effect of iron and transferrin on the response of serum-free cultures of mouse lymphocytes to concanavalin A and lipopolysaccharide. Immunology. 43:387-392.

62. Mainou-Fowler, T., and J. H. Brock. 1985. Effect of iron deficiency on the response of mouse lymphocytes to concanavalin A: The importance of transferrin-bound iron. Immunology. 54:325-332. 